\title{
Yield components and water use efficiency in coriander under irrigation and nitrogen fertilization
}

\author{
Karoline P. Angeli ${ }^{1}$, Fábio T. Delazari ${ }^{1}$, Carlos Nick $^{1}$, Mariane G. Ferreria ${ }^{1}$ \& Derly J. H. da Silva ${ }^{1}$ \\ ${ }^{1}$ Universidade Federal de Viçosa/Departamento de Fitotecnia. Viçosa, MG. E-mail: karoline.angeli@gmail.com; fabiodelazari@gmail.com (Corresponding \\ author); carlosnickg@gmail.com; mari.ferreira1010@gmail.com; derly@ufv.br
}

\section{Key words:}

Coriandrum sativum L. irrigation management water saving nitrogen fertilization

\begin{abstract}
A B S T R A C T
Among the determining factors of yield, nitrogen $(\mathrm{N})$ fertilization and the correct supply of water play an important role in the quality and yield aspects of coriander. Therefore, the aim of this study was to evaluate the yield components and the water use efficiency (WUE) in coriander subjected to different depths and $\mathrm{N}$ doses. A completely randomized design in split plot was used. Water depths were applied in the plots at the rates of 25, 50, 75, 100 and $125 \%$ of the Required Real Irrigation (RRI). N doses were distributed within the subplots at the following proportions: 50,100 and $150 \%$ of the recommendation for the crop (70 kg $\left.\mathrm{ha}^{-1}\right)$. The $\mathrm{N}$ dose of $94 \mathrm{~kg} \mathrm{ha}^{-1}$ and irrigation depth of $115 \%$ of RRI promoted the greatest yield $\left(29.0 \mathrm{t} \mathrm{ha}^{-1}\right)$ and number of bunches $\left(29\right.$ bunches $\left.\mathrm{m}^{-2}\right)$. The highest number of leaves per plant was obtained with the $\mathrm{N}$ dose of $103.2 \mathrm{~kg} \mathrm{ha}^{-1}$ and irrigation depth of $68 \%$ of the RRI. The maximum plant height $(43 \mathrm{~cm})$ was obtained with $\mathrm{N}$ dose of $105 \mathrm{~kg} \mathrm{ha}^{-1}$ and irrigation depth of $121 \%$ of RRI. The highest WUE in coriander $\left(71 \mathrm{~kg} \mathrm{~m}^{-3}\right)$ occurred at the irrigation depth of $26 \%$ of RRI and $\mathrm{N}$ dose of $105 \mathrm{~kg} \mathrm{ha}^{-1}$.
\end{abstract}

Palavras-chave: Coriandrum sativum L. manejo da irrigação economia de água adubação nitrogenada

\section{Componentes de produção e eficiência do uso d'água em coentro sob irrigação e adubação nitrogenada}

\begin{abstract}
R E S U M O
Dentre os fatores determinantes da produção a adubação nitrogenada e o suprimento adequado de água desempenham papel importante nos aspectos de qualidade e de produção do coentro. Portanto, objetivou-se avaliar os componentes de produção e a eficiência do uso da água (EUA) do coentro quando submetido a diferentes lâminas de irrigação e doses de nitrogênio. Foi empregado o delineamento inteiramente casualizado em esquema de parcelas subdivididas. As lâminas de irrigação foram aplicadas nas parcelas nos níveis: 25, 50, 75 , 100 e 125\% da Irrigação Real Necessária (IRN). Já as doses de nitrogênio foram distribuídas dentro das subparcelas nas seguintes proporções: 50, 100 e 150\% da recomendação para a cultura $\left(70 \mathrm{~kg} \mathrm{ha}^{-1}\right)$. A dose de nitrogênio e a lâmina de água que proporcionaram a maior produtividade e número de molhos foram de $94 \mathrm{~kg} \mathrm{ha}^{-1}$ e $115 \%$ da IRN, resultando em 29,0 $\mathrm{t} \mathrm{ha}^{-1}$ e 29 molhos $\mathrm{m}^{-2}$. O maior número de folhas por planta foi obtido com a dose de 103,2 $\mathrm{kg} \mathrm{ha}^{-1}$ de $\mathrm{N}$ e $68 \%$ da IRN. A altura máxima alcançada foi de $43 \mathrm{~cm}$, com $105 \mathrm{~kg} \mathrm{ha}^{-1}$ de N e $121 \%$ IRN. A maior EUA no coentro ocorreu para a lâmina de irrigação de $26 \%$ da IRN e a dose de nitrogênio de $105 \mathrm{~kg} \mathrm{ha}^{-1}$, o que resultou em uma EUA de $71 \mathrm{~kg} \mathrm{~m}^{-3}$.
\end{abstract}




\section{INTRODUCTION}

Coriander, Coriandrum sativum L., is a herbaceous annual vegetable, belonging to the Apiaceae family. The species is native to the Mediterranean and widely cultivated worldwide. Coriander is cultivated for the high commercial values of its leaves and seeds, considered as natural sources of essential oils used in the pharmaceutical and food industry, such as the petroselinic acid, geraniol, limonene and linalool (Carrubba, 2009; Hassan \& Ali, 2013). These characteristics qualify coriander as a medicinal and aromatic species.

In Brazil, coriander is mainly cultivated by small and medium farmers in the North and Northeast regions. Its main destination is the production of green mass for condimental use and fruits for industrial use (Maciel et al., 2012). However, there are reports of scarcity of research in Brazil on this crop, notably those related to new technologies that can be implemented in the production system (Pereira et al., 2005).

The requirement of water by the crop depends predominantly on the edaphoclimatic conditions; however, the uniform and continuous supply of water is desirable (Thamburaj \& Singh, 2004). In this context, inadequate irrigation management stands out among the limiting factors for the cultivation and production of this species.

In order to elucidate the consequences of the limitation in water supply on the yield and water use efficiency of coriander, it is suggested that, under water stress conditions, there is lower leaf area index, net assimilation rate and, consequently, lower growth (Drunasky \& Struve, 2005). Sharp deficits in the flowering stage result in drastic reductions in the production (Kumar et al., 2008). Recently, vegetative parameters such as plant height, number of ramifications and shoot fresh and dry matters have been maximized with high irrigation depths, confirming the previously mentioned results (Hassan \& Ali, 2013).

Regarding the coriander cultivation system, another production factor that must be considered is nitrogen $(\mathrm{N})$ fertilization. In aromatic species, the adequate $\mathrm{N}$ supply may have direct effect on the quality aspects, composition of volatile compounds and their primary yield components.

Studies on water deficit and $\mathrm{N}$ application in coriander have reported that significant increments in the production of fresh matter and seeds occurred at $\mathrm{N}$ doses higher than 80 $\mathrm{kg} \mathrm{ha}^{-1}$ (Silva et al., 2013). Similar results were obtained by Jamali (2012), who suggested that applications of $120 \mathrm{~kg} \mathrm{ha}^{-1}$ of $\mathrm{N}$ promoted higher growth rate in the crop combined with a greater leaf area index.

Coriander has variable response to $\mathrm{N}$ application and its use efficiency depends on the general conditions of soil fertility. Such dependence is probably the reason why the adequate supply of $\mathrm{N}$, along with application of optimal irrigation depths, increases the probability of maximizing production (Carrubba, 2009).

Considering the importance of the coriander crop and the lack of information on its water and nutritional requirements, this study aimed to evaluate the yield parameters and water use efficiency of coriander subjected to different irrigation depths and $\mathrm{N}$ fertilization doses.

\section{Material ANd Methods}

The experiment was conducted from September to October 2014 at the Research Vegetable Garden of the Federal University of Viçosa (UFV) in Viçosa-MG, Brazil (20 $45^{\prime} 14^{\prime \prime}$ S; 42 52' 53” W; $648 \mathrm{~m}$ ).

Soil chemical and physical-hydraulic characteristics are shown in Table 1.

Sowing was performed on September 19, 2014, on 200cell trays with the plant substrate Carolina ${ }^{\circ}$, Standard II EC = $1.5 \mathrm{mS} \mathrm{cm}^{-1}+/-0.3$ using three seeds per cell of the cultivar 'Vedete. The seedlings were transplanted on October 6, when they showed the first pair of definitive leaves, at the spacing of 0.05 by $0.20 \mathrm{~m}$.

The experiment was installed in a protected environment and the seedlings were arranged on 1.2-m-wide, 3-m-long beds. The experimental plots had total area of $0.6 \mathrm{~m}^{2}$ and evaluated area of $0.24 \mathrm{~m}^{2}$.

The experimental design was completely randomized (CRD) in split plot scheme, with five replicates. The plots were represented by the irrigation depths of $25,50,75,100$ and $125 \%$ of the required real irrigation (RRI). $\mathrm{N}$ doses were arranged in the subplots: 50,100 and $150 \%$ of the recommendation suggested by Oliveira et al. (2003).

Irrigation was performed using a dripping tape with flow rate of $1.13 \mathrm{~L} \mathrm{~h}^{-1}$, at the pressure of $78.453 \mathrm{kPa}$ and Christiansen's Uniformity Coefficient (CUC) of $97.9 \%$. The drippers were spaced by $0.20 \mathrm{~m}$ the dripping tapes were spaced by $0.30 \mathrm{~m}$ on the beds, resulting in an application intensity of $14.07 \mathrm{~mm} \mathrm{~h}^{-1}$.

Irrigation depth treatments were based on the required real irrigation (RRI), defined by Eq. 1 .

$$
\mathrm{RRI}=10 \times(\mathrm{FC}-\mathrm{PWP}) \times \mathrm{f} \times \mathrm{Z}
$$

where:

RRI - required real irrigation, $\mathrm{mm}$;

FC - field capacity, $\mathrm{m}^{3} \mathrm{~m}^{-3}$;

PWP - permanent wilting point, $\mathrm{m}^{3} \mathrm{~m}^{-3}$;

f - water availability factor; and,

$\mathrm{Z} \quad$ - effective root depth, $\mathrm{cm}$.

Irrigation depth management was based on the irrigation frequency of two to three days and water demand was

Table 1. Results of the chemical and physico-hydraulic analyses of the soil in the experimental area

\begin{tabular}{|c|c|c|c|c|c|c|c|c|c|c|c|c|c|c|c|c|c|}
\hline \multicolumn{7}{|c|}{ Soil physical-hydraulic properties } & \multicolumn{11}{|c|}{ Soil chemical properties } \\
\hline \multirow{2}{*}{$\begin{array}{l}\text { Layer } \\
\text { cm }\end{array}$} & $\mathrm{FC}^{1}$ & PWP2 $^{2}$ & Clay & Silt & Sand & \multirow{2}{*}{$\begin{array}{c}\text { Textural } \\
\text { class }\end{array}$} & \multirow{2}{*}{$\begin{array}{c}\mathrm{pH} \\
\mathrm{H}_{2} \mathrm{O}\end{array}$} & $\mathbf{P}$ & $\mathbf{K}$ & $\mathrm{Ca}^{2+}$ & $\mathrm{Mg}^{2+}$ & $\mathbf{A l}^{3+}$ & $\mathrm{H}+\mathrm{Al}$ & $\mathbf{T}$ & \multirow{2}{*}{$\begin{array}{l}\text { V } \\
\%\end{array}$} & \multirow{2}{*}{$\begin{array}{c}\text { OM } \\
{\text { dag } k^{-1}}^{-1}\end{array}$} & \multirow{2}{*}{$\begin{array}{l}\text { P-rem } \\
\mathrm{mg} \mathrm{L}^{-1}\end{array}$} \\
\hline & & & & $\%$ & & & & $\mathrm{mg} \mathrm{c}$ & $\mathrm{m}^{-3}$ & \multicolumn{5}{|c|}{$\mathrm{cmol}_{\mathrm{c}} \mathrm{dm}^{-3}$} & & & \\
\hline $0-20$ & 0.401 & 0.255 & 33 & 19 & 48 & Sandy clay loam & 6.3 & 126.1 & 189 & 7.3 & 1.5 & 0.0 & 2.15 & 11.4 & 81 & 3.10 & 34.3 \\
\hline
\end{tabular}

Available P, K, Fe, Zn, Mn and Cu extracted with Mehlich I; Exchangeable Ca, Mg and Al extracted with $1 \mathrm{~mol} \mathrm{~L}^{-1} \mathrm{KCl}^{1}{ }^{1}$ Field capacity, ${ }^{2}$ Permanent wilting point. Textural classification according

to the Brazilian Soil Science Society (Lemos \& Santos, 1996) 
calculated through the estimation of crop evapotranspiration (ETc), using adjustment coefficients in relation to the reference evapotranspiration $\left(\mathrm{ET}_{\mathrm{o}}\right)$.

The net irrigation depth was calculated using a water balance in which irrigation represented the inflow of water and $\mathrm{ET}_{\mathrm{c}}$ represented the outflow. Eqs. 2 and 3, proposed by Allen et al. (2006), were used to estimate crop evapotranspiration.

$$
\begin{gathered}
\mathrm{ET}_{\mathrm{c}}=\mathrm{ET}_{\mathrm{o}} \times \mathrm{K}_{\mathrm{c}} \\
\mathrm{K}_{\mathrm{c}}=\left(\mathrm{K}_{\mathrm{cb}} \times \mathrm{K}_{\mathrm{s}}\right)+\mathrm{K}_{\mathrm{e}}
\end{gathered}
$$

where:

$$
\begin{array}{ll}
\mathrm{ET}_{\mathrm{c}} & \text { - crop evapotranspiration, } \mathrm{mm} \mathrm{d}^{-1} ; \\
\mathrm{ET}_{\mathrm{o}} & \text { - reference evapotranspiration, } \mathrm{mm} \mathrm{d}^{-1} \text {; } \\
\mathrm{K}_{\mathrm{c}} & \text { - crop coefficient; } \\
\mathrm{K}_{\mathrm{cb}} & \text { - basal crop coefficient; } \\
\mathrm{K}_{\mathrm{e}} & \text { - soil evaporation coefficient; and, } \\
\mathrm{K}_{\mathrm{s}} & \text { - stress coefficient. }
\end{array}
$$

Crop cycle was divided into phenological stages, based on the growth period or vegetative period related to the shading of the area, and each stage assumed a different value of crop coefficient $(\mathrm{Kc})$. Coriander Kc values are influenced by the characteristics of its development stage and general edaphoclimatic conditions (Allen et al., 2006).

Calculations were performed using the values of initial, intermediate and final $\mathrm{K}_{\mathrm{cb}}$, respectively of $0.2,1.05$ and 0.6 (Silva et al., 2013).

The first phenological stage began immediately after the transplantation of the seedlings and continued until close to $10 \%$ of shaded area, which corresponded to a period of 6 days. The second stage lasted for 9 days and finished when about $75 \%$ of the area was covered by the crop. The third crop stage began when $75 \%$ of the area was shaded (Allen et al., 2006) and continued until the total cover of the area, with duration of 10 days. The last stage corresponded to a period of 4 days, until crop harvest.

Soil acidity was not corrected because $\mathrm{pH}$ remained close to the recommended value of 6.3; fertilization was based on the study of Oliveira et al. (2003), using, at transplantation, $60 \mathrm{~kg}$ $\mathrm{ha}^{-1}$ of $\mathrm{P}_{2} \mathrm{O}_{5}$ and $11 \mathrm{~kg} \mathrm{ha}^{-1}$ of $\mathrm{N}$ in the form of monoammonium phosphate (MAP) $\left(45 \% \mathrm{P}_{2} \mathrm{O}_{5}\right.$ and $\left.9 \% \mathrm{~N}\right)$; the rest of $\mathrm{N}$ fertilization was divided and urea was used as the $\mathrm{N}$ source, as shown in Table 2.

\begin{tabular}{|c|c|c|c|c|}
\hline \multirow{3}{*}{ Treatment } & \multicolumn{4}{|c|}{ Applied doses of $\mathrm{N}$ and fertilizer $\left(\mathrm{kg} \mathrm{ha}^{-1}\right)$} \\
\hline & \multicolumn{2}{|c|}{ Planting } & \multicolumn{2}{|c|}{ Top-dressing } \\
\hline & $\mathbf{N}$ & MAP & $\mathbf{N}$ & Urea \\
\hline D1 & 11 & 125 & 24 & 53 \\
\hline $\mathrm{D} 2$ & 11 & 125 & 59 & 131 \\
\hline D3 & 11 & 125 & 94 & 208 \\
\hline
\end{tabular}

After reaching the commercial size, from 20 to $30 \mathrm{~cm}$, five central plants of each treatment were collected and plant height was recorded. After harvest, cuts were performed in order to separate shoots from roots; the shoots were weighed and the number of leaves was counted and separated in 100-g bunches,

Table 2. Total of nitrogen $(\mathrm{N})$ applied in different treatments in the experiment while the roots were washed and weighed. Water use efficiency (WUE) was also evaluated and defined by the relationship between production $(\mathrm{P})$ and the applied water volume $(\mathrm{V})$, expressed in $\mathrm{kg} \mathrm{m}^{-3}$ (Eq. 4).

$$
\mathrm{WUE}=\frac{\mathrm{P}}{\mathrm{V}}
$$

where:

WUE - water use efficiency, $\mathrm{kg} \mathrm{m}^{-3}$;

$\mathrm{P}$ - production, $\mathrm{kg}$; and,

$\mathrm{V} \quad$ - applied water volume (irrigation), $\mathrm{m}^{3}$.

The data were analysed through linear regression; for irrigation depth and fertilization doses, the regression models were selected based on the significance of the regression coefficients, using the t-test at 0.01 and 0.05 probability levels.

\section{Results AND Discussion}

The data of maximum, medium and minimum temperatures $\left({ }^{\circ} \mathrm{C}\right)$ and relative air humidity $(\%)$, solar radiation $\left(\mathrm{W} \mathrm{m}^{-2}\right)$ and reference evapotranspiration (ETo, in $\mathrm{mm} \mathrm{d}^{-1}$ ), used for the irrigation management are shown in Figure 1A and 1B.

Water balance, upper limit (field capacity) and lower limit (permanent wilting point), irrigation, water availability factor (f) (30\%) and soil water content for the treatment with irrigation depth of $100 \%$ are shown in Figure 2.

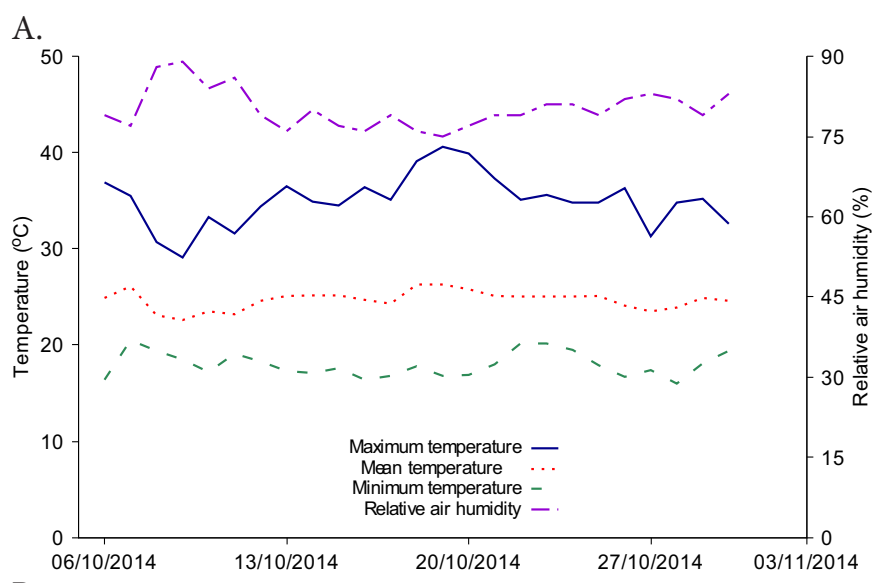

B.

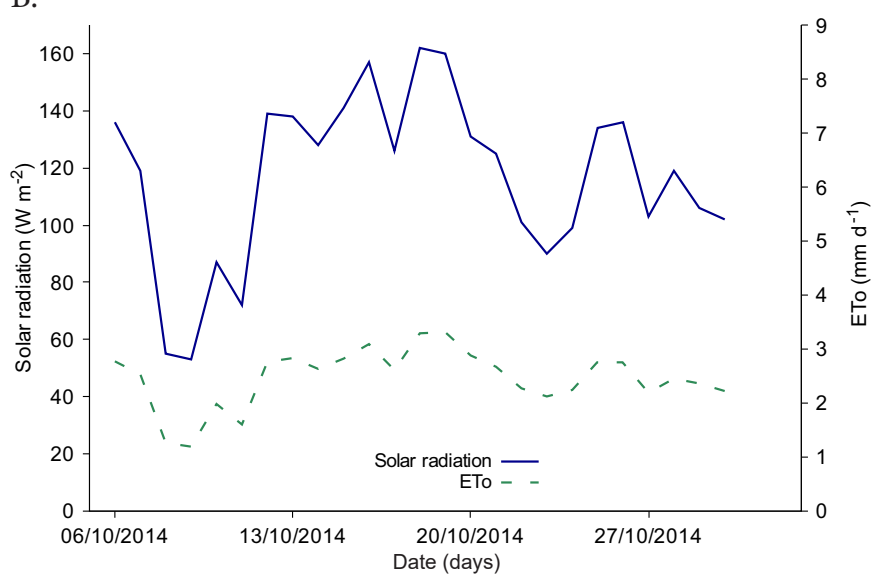

Figure 1. Maximum, medium and minimum temperatures, relative air humidity $(\mathrm{A})$ and solar radiation and reference evapotranspiration (B) for the coriander cultivation period 


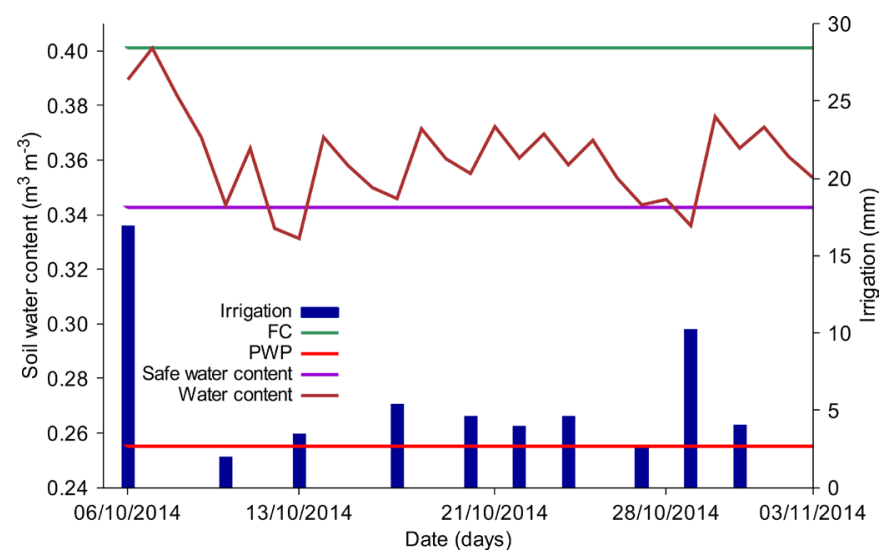

Figure 2. Water balance for the irrigation depth of $100 \%$ and limits of soil water storage (field capacity-FC and permanent wilting point-PWP) for coriander management

The response surfaces for coriander yield (Figure 3A) and number of bunches (Figure $3 \mathrm{~B}$ ) as a function of irrigation

A.

$$
\begin{aligned}
& \hat{\mathrm{Y}}=-1.60642+0.03184^{*+*} \mathrm{~N}+0.09638^{* * * *} \mathrm{I}-0.00017^{* *} \mathrm{~N}^{2}-0.00077^{* *} \mathrm{I}^{2} \\
& \mathrm{R}^{2}=0.7853
\end{aligned}
$$

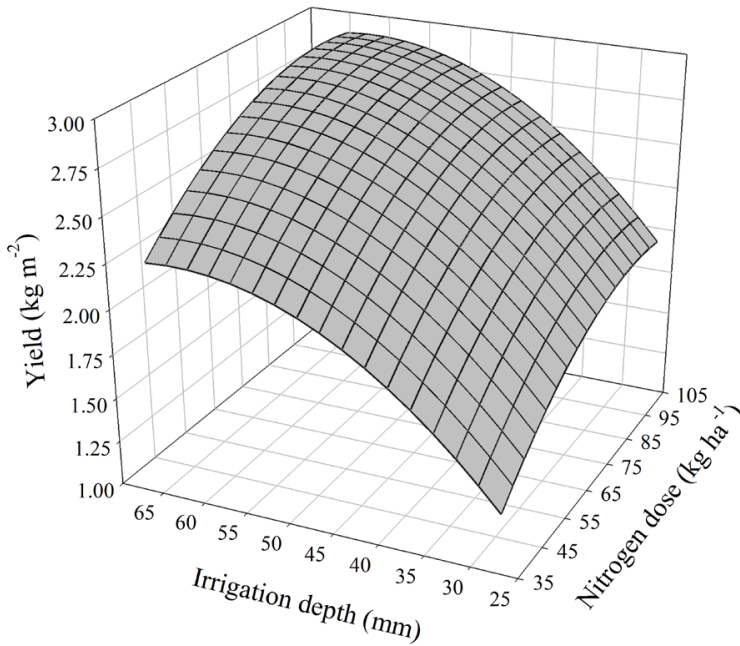

B.

$$
\begin{aligned}
& \hat{\mathrm{N} B}=-16.0642+0.3184^{* * *} \mathrm{~N}+0.9638^{* * * *} \mathrm{I}^{2}-0.0017^{* * *} \mathrm{~N}-0.0077^{* *} \mathrm{I}^{2} \\
& \mathrm{R}^{2}=0.7853
\end{aligned}
$$

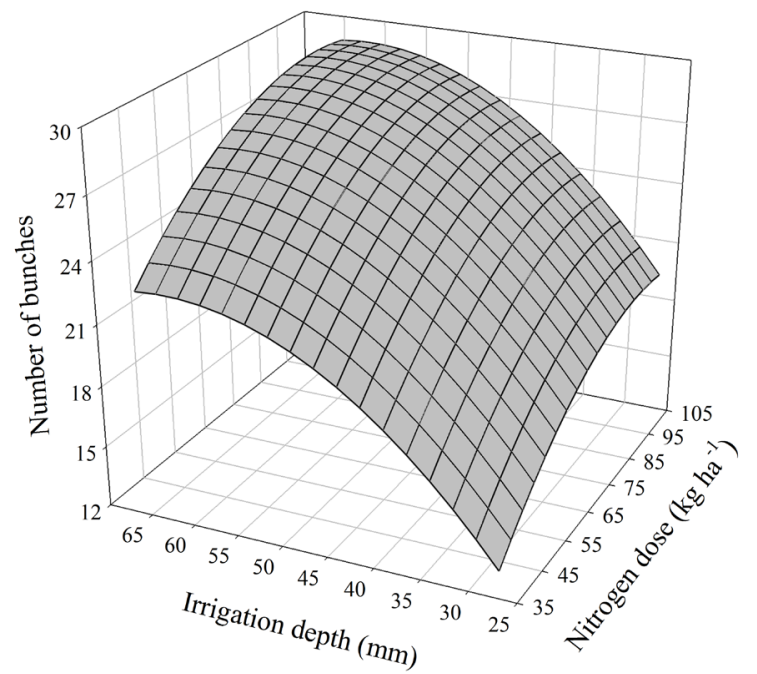

Figure 3. Response surface of coriander yield and number of bunches per $\mathrm{m}^{2}$ as a function of irrigation depth (I) and nitrogen dose $(\mathrm{N})$ depths and $\mathrm{N}$ doses are shown in Figure 3. The irrigation depth of $63 \mathrm{~mm}$ and $\mathrm{N}$ dose of $94 \mathrm{~kg} \mathrm{ha}^{-1}$ caused maximum yield (2.90 $\mathrm{kg} \mathrm{m}^{-2}$ ) and number of bunches (29 bunches $\mathrm{m}^{-2}$ ).

These results suggest the presence of positive correlation of coriander yield and number of leaves with irrigation depth and $\mathrm{N}$ doses. Oliveira et al. (2003), evaluating the effect of different $\mathrm{N}$ doses on crop production components, observed increments of $0.0256 \mathrm{~kg} \mathrm{~m}^{-2}$ in coriander green mass for each $\mathrm{kg}$ of $\mathrm{N} \mathrm{ha}^{-1}$ added to the soil, with maximum yield of $5.4 \mathrm{~kg} \mathrm{~m}^{-2}$.

Shanu et al. (2013) evaluated the effect of different irrigation depths and observed yield of $2.1 \mathrm{~kg} \mathrm{~m}^{-2}$ at the highest irrigation depth applied. Jamali \& Martirosyan (2013) studied the effect of two levels of water replenishment, 30 and $70 \mathrm{~mm}$ of crop evapotranspiration, combined with four doses of $\mathrm{N}$ and four doses of $\mathrm{P}$, and observed that maximum $\mathrm{N}$ and $\mathrm{P}$ doses promoted yield of $1.24 \mathrm{~kg} \mathrm{~m}^{-2}$, when combined with water replenishment level of $30 \mathrm{~mm}$. These values are lower than those observed in the present study.

As to the number of coriander bunches, which are the main form of commercialization and thus of great importance for the producer, Barros Júnior et al. (2004) obtained the value of 3.4 bunches $\mathrm{m}^{-2}$, evaluating the agronomic performance of commercial cultivars of coriander under high temperature conditions. This result is much lower than that obtained in the present study ( 29 bunches $\mathrm{m}^{-2}$ ).

Figure 4 shows the response surface for plant height (Figure $4 \mathrm{~A}$ ) and number of leaves (Figure $4 \mathrm{~B}$ ) of coriander as a function of the irrigation depths and $\mathrm{N}$ doses. The combination between irrigation depths of 65 and $44 \mathrm{~mm}$ and $\mathrm{N}$ doses of 105 and 103 $\mathrm{kg} \mathrm{ha}^{-1}$, respectively, caused the highest values of plant height $(43 \mathrm{~cm})$ and number of leaves (27 leaves per plant).

These results indicate a positive correlation of plant height and number of leaves with irrigation depth and $\mathrm{N}$ doses, due to the increment in parameters related to the vegetative growth of coriander. Jamali \& Martirosyan (2013) observed greater value of plant height $(52.6 \mathrm{~cm})$ with higher irrigation frequency $(30 \mathrm{~mm})$, combined with maximum doses of $\mathrm{N}$ and $\mathrm{P}$, a value higher than that in the present study.

The response surface for the water use efficiency of coriander as a function of irrigation depths and $\mathrm{N}$ doses is shown in Figure 5. The combination between irrigation depth of $27 \mathrm{~mm}$ and $\mathrm{N}$ dose of $105 \mathrm{~kg} \mathrm{ha}^{-1}$ caused the highest WUE $\left(71.0 \mathrm{~kg} \mathrm{~m}^{-3}\right)$

This result is similar to those observed by Monteiro et al. (2008) and Barros et al. (2002), who evaluated WUE increment at various fertilization doses. Lopes (1989) observed that WUE increases with the practice of fertilization, provided that yield also increases.

The following WUE values were observed in some fruitproducing species: tomato, $12.5 \mathrm{~kg} \mathrm{~m}^{-3}$ (Silva et al., 2013); watermelon, $24.3 \mathrm{~kg} \mathrm{~m}^{-3}$ (Morais et al., 2008) and melon, $30.0 \mathrm{~kg} \mathrm{~m}^{-3}$ (Sousa et al., 2000); tuberous roots, such as sweet potato, may reach $20.0 \mathrm{~kg} \mathrm{~m}^{-3}$ (Mantovani et al., 2013). Silva \& Queiroz (2013) studied lettuce and observed WUE of 14.1 $\mathrm{kg} \mathrm{m}^{-3}$. These results suggest that coriander has higher WUE compared with the previously mentioned species. According to Oliveira et al. (2012), crops with higher WUE are of great importance when it comes to the economy of water resources, because they allow greater yield per $\mathrm{m}^{3}$ of water. 
A.

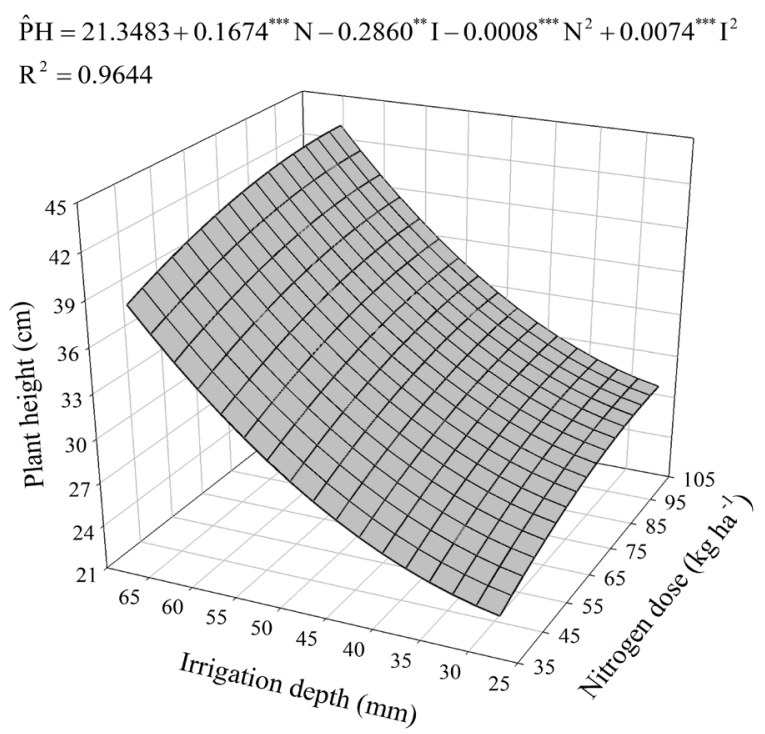

B.

$$
\begin{aligned}
& \hat{\mathrm{N}} \mathrm{L}=2.6650+0.1857^{* * * *} \mathrm{~N}+0.6794^{* * * t} \mathrm{I}-0.0009^{* * *} \mathrm{~N}^{2}-0.0077^{* * z} \mathrm{I}^{2} \\
& \mathrm{R}^{2}=0.6950
\end{aligned}
$$

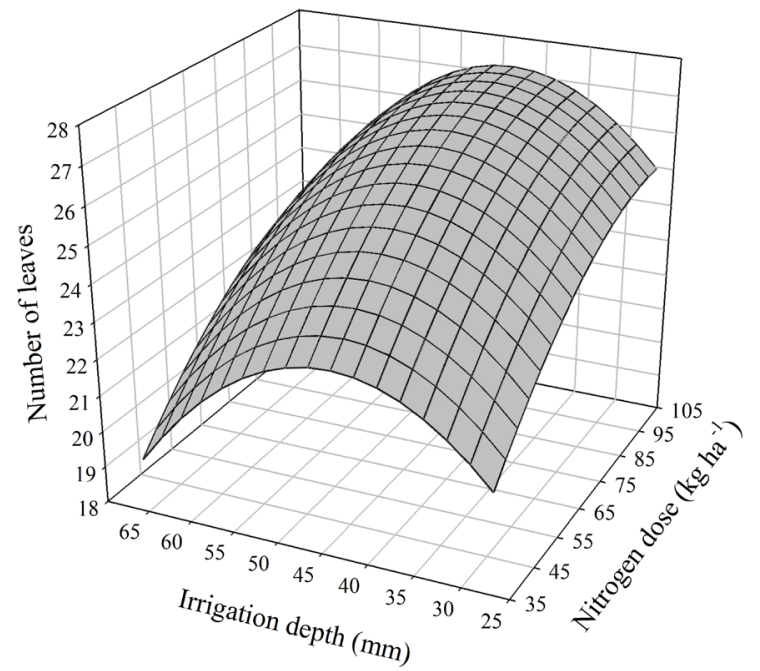

Figure 4. Plant height (PH) and number of leaves (NL) of coriander as a function of irrigation depth (I) and nitrogen dose $(\mathrm{N})$

Coriander WUE was very high, in comparison to the other crops, when the irrigation depth of $63 \mathrm{~mm}$ was used. This irrigation depth allowed greater efficiency in the use of water, with production of $49.8 \mathrm{~kg} \mathrm{~m}^{-3}$. Since the market does not yet pay for products with high water use efficiency, it was decided to value only the yield; however, this must change with the climatic changes and the reduction in the frequency of rains.

\section{Conclusions}

1. The evaluated parameters (yield, number of bunches, plant height, number of leaves and water use efficiency) were influenced by irrigation depth and nitrogen doses.

2. The highest water use efficiency of coriander $\left(71 \mathrm{~kg} \mathrm{~m}^{-3}\right)$ was obtained at the irrigation depth of $27 \mathrm{~mm}$ (26\% required real irrigation) and nitrogen dose of $105 \mathrm{~kg} \mathrm{ha}^{-1}$.

3. The nitrogen dose of $94 \mathrm{~kg} \mathrm{ha}^{-1}$ and irrigation depth of $63 \mathrm{~mm}$ (115\% required real irrigation) caused the highest yield $\left(29,000 \mathrm{~kg} \mathrm{ha}^{-1}\right)$ and number of bunches (29 bunches $\left.\mathrm{m}^{-2}\right)$.

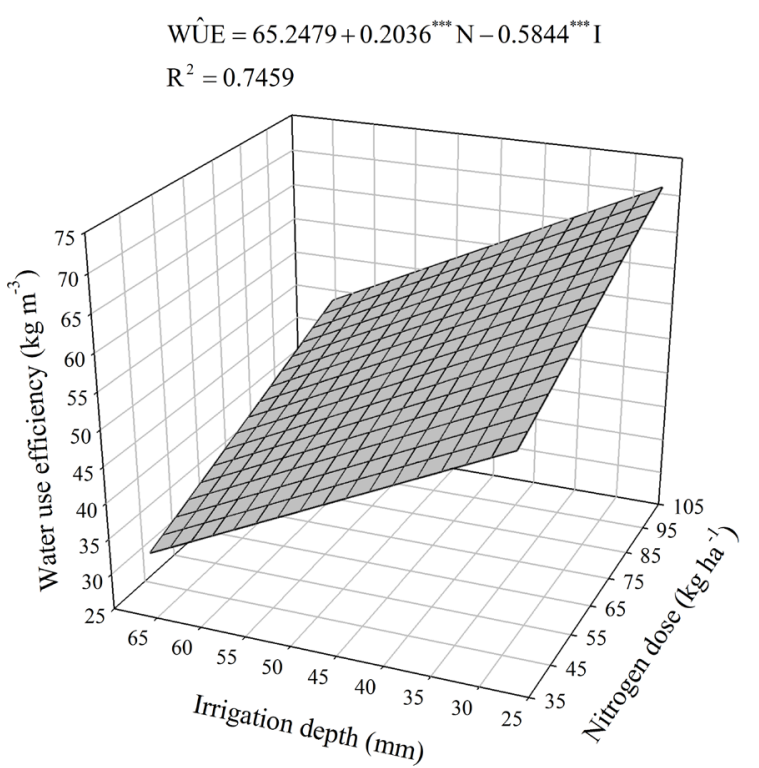

Figure 5. Water use efficiency (WUE) as a function of the applied irrigation depth (I) and nitrogen dose (N)

4. The highest number of leaves (27 leaves plant $\left.{ }^{-1}\right)$ was obtained at the nitrogen dose of $103 \mathrm{~kg} \mathrm{ha}^{-1}$ and irrigation depth of $44 \mathrm{~mm}$ (68\% required real irrigation).

5. The maximum plant height $(43 \mathrm{~cm})$ was obtained at the nitrogen dose of $105 \mathrm{~kg} \mathrm{ha}^{-1}$ and irrigation depth of $65 \mathrm{~mm}$ (121\% required real irrigation).

6. The most important parameter for the farmer is yield; thus, irrigation depth of $63 \mathrm{~mm}$ (115\% required real irrigation) and nitrogen dose of $94 \mathrm{~kg} \mathrm{ha}^{-1}$ are recommended for higher coriander yield.

\section{Literature Cited}

Allen, R. G.; Pereira, L. S.; Raes, D.; Smith, J. Evapotranspiration del cultivo: Guias para la determinación de los requerimientos de agua de los cultivos. Roma: FAO, 2006. 298p.

Barros, V. da S.; Costa, R. N. T.; Aguiar, J. V. Função de produção de cultura do melão para níveis de água e adubação nitrogenada no vale do Curu - CE. Revista Irriga, v.7, p.98-105, 2002. http:// dx.doi.org/10.15809/irriga.2002v7n2p98

Barros Júnior, A. P.; Bezerra Neto, F.; Negreiros, M.; Oliveira, E.; Silveira, L.; Câmara, M. Desempenho agronômico de cultivares comerciais de coentro em cultivo solteiro sob condições de temperatura elevada e ampla luminosidade. Caatinga, p.409-416, v.17, 2004.

Carrubba, A. Nitrogen fertilisation in coriander (Coriandrum sativum L.): A review andmeta-analysis. Journal of the Science of Food and Agriculture, v.89, p.921-926, 2009. http://dx.doi.org/10.1002/ jsfa. 3535

Drunasky, N.; Struve, D. K. Quercus macrocarpa and Q. prinus physiological responses to drought stress and their potencial for urban forestry. Urban For. \& Urban Greed, v.4, p.13-22, 2005. http://dx.doi.org/10.1016/j.ufug.2005.07.001

Hassan, F. A. S.; Ali, E. F. Impact of different water regimes based on class-A pan on growth, yield and oil content of Coriandrum sativum L. plant. Journal of the Saudi Society of Agricultural Sciences, v.13, p.155-161, 2013. http://dx.doi.org/10.1016/j. jssas.2013.05.001 
Jamali, M. M. Investigate the effect of drought stress and different amount of chemical fertilizers on some physiological characteristics of coriander (Coriandrum sativum L.), International journal of Agronomy and Plant Production, v.3, p.585-589, 2012.

Jamali, M. M.; Martirosyan, H. Evaluate the effect of water deficit and chemical fertilizers on some characteristics of coriander (Coriandrum sativum L.). International journal of Agronomy and Plant Production, v.4, p.413-417, 2013.

Kumar, A; Singh, R; Chhillar R. K. Influence of omitting irrigation and nitrogen levels on growth, yield and water use efficiency of coriander (Coriandrum sativum L.) Acta Agronomica Hungarica, v.56, p.69-74, 2008. http://dx.doi.org/10.1556/AAgr.56.2008.1.7

Lemos, R. C.; Santos, R. D. Manual de descrição e coleta de solo no campo. 3.ed. Campinas: Sociedade Brasileira de Ciência do Solo/ Embrapa CNPS, 1996. 83p.

Lopes, A. S. Manual de fertilidade do solo. São Paulo: ANDA/Potafos, 1989. 153p.

Maciel, G. M.; Costa, C. P.; Sala, F. C. Linhagens de coentro com pendoamento tardio sob dois sistemas de plantio. Horticultura Brasileira, v.30, p.607-612, 2012. http://dx.doi.org/10.1590/S010205362012000400008

Mantovani, E. C.; Delazari, F. T.; Dias, L. E.; Assis, I. R.; Vieira, G. H. S.; Landim, F. M. Eficiência no uso da água de duas cultivares de batata-doce em resposta a diferentes lâminas de irrigação. Revista Horticultura Brasileira, v.31, p.602-606, 2013. http:// dx.doi.org/10.1590/S0102-05362013000400015

Monteiro, R. O. C.; Costa, R. N. T.; Leão, M. C. S.; Aguiar, J. V. de. Eficiência do uso da água e nitrogênio na produção de melão. Revista Irriga, v.13, p.367-377, 2008.

Morais, N. B.; Bezerra, F. M. L.; Medeiros, J. F.; Chaves, S. W. P. Resposta de plantas de melancia cultivadas sob diferentes níveis de água e de nitrogênio. Revista Ciência Agronômica, v.39, p.369-377, 2008.

Oliveira, A. P.; Paiva Sobrinho, S.; Barbosa, J. K. A.; Ramalho, C. I.; Oliveira, A. L. P. Rendimento de coentro cultivado com doses crescentes de N. Horticultura Brasileira, v.21, p.81-83, 2003. http:// dx.doi.org/10.1590/S0102-05362003000100017
Oliveira, P. G. F.; Moreira O. C.; Branco L. M. C.; Costa R. N. T.; Dias C.N. Eficiência de uso dos fatores de produção água e potássio na cultura da melancia irrigada com água de reuso. Revista Brasileira de Engenharia Agrícola e Ambiental, v.16, p.153-158, 2012. http:// dx.doi.org/10.1590/S1415-43662012000200004

Pereira, R. S.; Muniz, M. F. B.; Nascimento, W. M. Aspectos relacionados à qualidade de sementes de coentro. Horticultura Brasileira, v.23, p.703-706, 2005. http://dx.doi.org/10.1590/S010205362005000300002

Silva, J. M.; Ferreira, R. S.; Melo, A. S.; Suassuna, J. F.; Dutra, A. F.; Gomes, J. P. Cultivo do tomateiro em ambiente protegido sob diferentes taxas de reposição da evapotranspiração. Revista Brasileira de Engenharia Agrícola e Ambiental, v.17, p.40-46, 2013. http://dx.doi.org/10.1590/S1415-43662013000100006

Silva, V. D.; Queiroz, S. O. P. Manejo de água para produção de alface em ambiente Protegido. Revista Irriga, v.18, p.184-199, 2013. http://dx.doi.org/10.15809/irriga.2013v18n1p184

Silva, V. P. R.; Tavares, A. L.; Sousa, I. F. Evapotranspiração e coeficientes de cultivo simples e dual do coentro. Horticultura Brasileira, v.31, p.255-259, 2013. http://dx.doi.org/10.1590/S010205362013000200013

Shanu, I. S.; Singh, R. P.; Shaktawat, R. P. S.; Verma, K. S. Effect of seed treatment and foliar spray of thiourea on growth, yield and quality of coriander (Coriandrum sativum L.) under different irrigation levels. International. Journal Seed Spices, v.3, p.20-25, 2013.

Sousa, V. F.; Coelho, E. F.; Junior, A. S. A.; Folegatti, M. V.; Frizzone, J. A. Eficiência do uso da água pelo meloeiro sob diferentes frequências de irrigação. Revista Brasileira de Engenharia Agrícola e Ambiental, v.4, p.183-188, 2000. http://dx.doi. org/10.1590/S1415-43662000000200009

Thamburaj, S.; Singh, N. Vegetables, tuber crops and spices. Kuldeep sharma, incharge, New Delhi Directorate of Information and Publication of Agriculture. Pusa: Indian Council of Agriculture Research, Krishi Anusandhan Bhaban, 2004. 115p. 